\title{
Genetic Study of Nutritional and Physicochemical Characters of Chickpea Lines and Cultivars (Cicer arietinum L.)
}

\author{
Kaouthar Bayahi ${ }^{1,2} \&$ Salah Rezgui ${ }^{2}$ \\ ${ }^{1}$ Departement of Biological Sciences Genetics and Molecular Biology, Faculty of Sciences of Tunis, University \\ of Tunis el Manar, Tunis, Tunisia \\ 2 Department ABV, National Agronomical Institute of Tunisia, Tunis, Tunisia \\ Correspondence: Kaouthar Bayahi, Departement of Biological Sciences Genetics and Molecular Biology, \\ Faculty of sciences of Tunis (FST), University of Tunis el Manar, Campus Universitaire 2092-El Manar Tunis, \\ Tunisia. E-mail: kaouthar-bayahi@hotmail.com
}

Received: November 20, 2016

doi:10.5539/jas.v9n3p151
Accepted: December 23, 2016

Online Published: February 15, 2017

\begin{abstract}
Sixteen Kabuli chickpea lines composed of five varieties released in Tunisia and eleven breeding lines originated from ICARDA have been analyzed to measure their nutritional and physicochemical properties and to evaluate their seed quality. The analysis showed variability among the investigated material in terms of physicochemical characteristics of seeds (weight of 100 seeds, caliber, hydration capacity, inflation capacity) and flour (density, index of color and rate of proteins) and time of cooking (Table 2).

The correlations between nutritional and physicochemical characters showed that they were significant between the weight of 100 seeds and the caliber (0.902), the time of cooking and the caliber $(0.421)$, the index of color and the caliber (-0.334), the weight of 100 seeds and the capacity of hydration (0.580). High heritability was characterizing all the characters excepting the density, humidity and the ashes.

The results show that the qualitative improvement of these traits is possible in early generations of a breeding program.

The effect of supplementary irrigation was beneficial on the caliber of seeds, the weight of 100 grains, the hydration capacity and the rate of proteins.

We consider that the genetics and the agricultural techniques take an equivalent part in the improvement of the quality on chickpea
\end{abstract}

Keywords: chickpea, quality improvement, rate of proteins, weight of 100 seeds, cooking time, caliber of seeds

\section{Introduction}

The chickpea is considered to be a very healthy vegetarian and important human food in south Asia and Sub Saharan Africa. It is a cheap source of high quality proteins in the diets of populations in developing countries where animal protein is unaffordable for most of people.

Chickpea has been specifically used to treat protein malnutrition and kwashiorkor in children (Krishna Murti, 1975). The protein concentration of chickpea seed is commonly 2-3 times higher than cereal grains. In addition to proteins, it is a good source of carbohydrates, minerals and trace elements (Williams \& Singh, 1988). The WHO recommends high consumption of energy-dilute foods rich in non-starch polysaccharides (NSPs) such as chickpea (WHO/FAO, 2003).

Chickpea brings taste and texture to the cereal dish and also carbohydrates and minerals, which ensure a balanced diet with all nutrient requirements (Duhan, Khetarpaul, \& Bishnoi, 1999). Its flour is used in many ways to cooking in a variety of Mediteranean and Asian dishes. e.g. couscous, lablabi, chapatti, hommous, roti.

Young plants and green pods are consumed like spinach. Among food legumes, chickpea is the most hypocholesterolemic and germinated chickpea is reported to be effective in controlling cholesterol in rats (Gervani, 1991). 
Despite the favorable nutritional profile, chickpea has several limitations such as a prolonged cooking time hard to cook phenomenon and poor digestibility. Some works have also reported variations in the physical and chemical compositions (Rupperez, 1998). These variations are due to genetic factors or to extrinsec factors like the storage, soil, agronomic practices, climatic factors and technological treatment (Paolini et al., 2003).

The chickpea quality has an increasingly important concern in marketing from the viewpoint of the raw material processor, the consumer and the breeder. Therefore, quality characteristics like seed mass, seed volume, hydration capacity, swelling capacity, storability, cooking quality and digestibility are receiving more attention for their role in the added value.

Chicpea protein digestibility is the highest among food legumes but it can be improved with cooking and rosting. The most important factors to breed for, are sulphur aminoacids, tryptophan, lysine, protein, large see size, regular seed shape, low decortications loss and low gasogen content. These are not in order of importance, since all are equally important (Williams \& Singh, 1986).

Kaur et al. (2005) showed a negative correlation between the properties of inflation during the roasting and the weight, the volume and the capacity of hydration of the seeds of chickpea. The properties of pastas stemming from some flour of chickpeas $(8 \%$ and $28 \% \mathrm{w} / \mathrm{w})$ were also deserving interest and were characterized for different cultivars (Kaur \& Singh, 2005). Some other works observed influence of growing environment upon cooking time and that correlation between the cooking times of soaked and unsoaked chickpea were not high suggesting that the factors contributing towards cooking time were affected to different degrees by the soaking which leads that cooking time is less important in breeding program (Williams \& Nakkoul, 1983). Despite published works describing the chemical and nutritional composition of chickpea, overall information is fragmentary and a comprehensive knowledge of the nutritional value describing cultivar influence on nutritional quality is lacking. However the realized works do not totally cover the relationships between characters of qualitative type so this study is focusing on the proteins and physicochemical characters since they represent most important quality criteria in Chickpea. Cooking, nutritional and physicochemical qualities to be evaluated in a breeding program require to developp methods for fast evaluation of these features. The study of correlations may be of importance for breeding studies in selecting for improved chickpea with high nutrient quality. The present study presents an attempt to give knowledge by physicochemical and nutritional correlations evaluation.

Despite the higher yield potential of winter-sown chickpea in West Asia and North Africa, spring-planted varieties may, in certain areas, be the only option to produce disease-free seed. However, spring-sown crops require one or two supplementary furrow irrigations to obtain a good yield. So we have also compared quality traits when we have supplied with one, two and three irrigations.

\section{Method}

Sixteen cultivars (representing a wide variation of winter chickpea from ICARDA) were sown according to a randomized block design with three replications. Twenty seeds of each kabuli chickpea cultivar (Cicer arietinum L.), grown and harvested under similar environmental and climatological conditions. A supplemental irrigation was practiced at mid-March, and April because spring was dry and hot.

The block one have beneficiated of three irrigations, the block two had two irrigations and the block three only one. 
Table 1. Plan of the randomized parcel

\begin{tabular}{lllll}
\hline TRT line & Lines & Rep. 1 Block 1 & Rep. 2 Block 2 & Rep. 3 Block 3 \\
\hline 1 & FLIP97-25C-W5 & 101 & 205 & 309 \\
2 & FLIP97-28C-W1 & 102 & 201 & 302 \\
3 & FLIP98-22C & 103 & 213 & 307 \\
4 & FLIP98-55C & 104 & 209 & 316 \\
5 & X96TH24-A2-W1-A1-W1-W1-W1 & 105 & 206 & 301 \\
6 & X96TH61-A3-W1-A2-W1-A1-W1-W1 & 106 & 202 & 310 \\
7 & X96TH63-A2-A1-A1-A1-A1-W1 & 107 & 214 & 315 \\
8 & X97TH85-W1-A1-A2-W1-W2 & 108 & 210 & 308 \\
9 & X98TH74-A4-A1-A1-A1 & 109 & 207 & 305 \\
10 & X98TH86-W9-W1-A1-A1 & 110 & 203 & 314 \\
11 & X2000TH129-A12-W2-A1 & 111 & 311 \\
12 & Kasseb & 112 & 215 & 304 \\
13 & Chétoui & 113 & 211 & 313 \\
14 & Bouchra & 114 & 208 & 306 \\
15 & Neyer & 115 & 204 & 303 \\
16 & Béja 1 & 116 & 216 & 312 \\
\hline
\end{tabular}

\subsection{Physical Characteristics of Seeds}

The studied material consists of the seeds stemming from the harvest and of flour of grinding finely the seeds. Harvesting was in June by pulling up all plants and keeping them in ambient conditions. Three Random samples of 100 seeds from each cultivar per replication were formed to be analyzed for the following post harvest physicochemical properties of seeds and nutritional trait of flour.

(1) Seed weight (PG) was determined by weighing three samples of 100 seeds of each genotype and block.

(2) Caliber of seeds $(\mathrm{CAL})=\sum$ (Number of grains $\times$ Diameter of sieve $) / 100$

(3) Hydration capacity $(\mathrm{CAPHY})=\left[Y-\left(X-(X / 100) \times N_{2}\right)\right] /\left(N_{1}-N_{2}\right) \mathrm{g} /$ grain

Where, $Y$ : weight of grains after hydration; $X$ : weight of dry grains; $N_{1}$ : number of total grains; $N_{2}$ : number of no hydrated grains.

(4) Capacity of inflation (CAPGO) $=\left(Y_{1}-Y_{2}\right)-\left[\left(X_{1}-X_{2}\right)-\left(X_{1}-X_{2} \times N_{2}\right)\right] /\left(N_{1}-N_{2}\right) \mathrm{g} /$ grain

Where, $Y_{1}$ : volume of water + hydrated grains; $Y_{2}$ : volume of water added to hydrated grains; $X_{1}=$ volume of water + dry grains; $X_{2}=$ volume of water added to dry grains; $N_{1}=$ number of total grains; $N_{2}=$ number of non hydrated grains.

(5) Cooking time (TCUI).

(6) Humidity $(\mathrm{HUM})=\left(m_{1}-m_{2}\right) /\left(m_{1}-m\right) \times 100$

Where, $m$ : mass of empty capsule; $m_{1}$ : mass of the sample before drying; $m_{2}$ : mass of the sample after drying.

(7) Rate of ashes $(\mathrm{CEND})=($ Dry residue $\times 100) /(100-$ Initial moisture content $\%)$

(8) Rate of proteins $(\mathrm{Pr})$ is measured according to the method of Kjeldhal: $(\mathrm{Pr})=\% \mathrm{~N} \times 6.25$

(9) Density (DT) $=$ mass initial/firmly packed volume $(\mathrm{mg} / \mathrm{ml})$

(10) Color of the flour $(\mathrm{CI})=\left(\mathrm{a}^{*} \times 1000\right) /\left(\mathrm{L}^{*} \times \mathrm{b}^{*}\right)$

Where, $\mathrm{L}^{*}$ defines the luminescence; $\mathrm{a}^{*}$ and $\mathrm{b}^{*}$ are chromatic components which define the green up to the red and the blue until the yellow respectively; $\mathrm{a}, \mathrm{b}^{*}$ and $\mathrm{L}^{*}$ are indicated by the Spectro-colorimeter (Jimenez-Cuesta et al., 1981).

All the tests are relative to the method of William et al. (2006) and the rate of proteins according to the method of Kjeldahl. 


\subsection{Statistical Analysis}

The data were statistically analyzed using the software SAS Version 9.0 with PROC ANOVA procedure LSD option for the mean comparison; and PROC VARCOMP procedure for the heritability assessment. The study of correlations was performed with SPSS STATISTICS 17.0 with Bivariate Correlate Analyzing procedure.

\section{Results and Discussion}

\subsection{Mean Value of the Studied Characters}

Table 2. Mean value of physicochemical and nutritional characters of sixteen chickpea lines and cultivars

\begin{tabular}{llllllllllllllllll}
\hline C & \multicolumn{1}{c}{} & 1 & 2 & 3 & 4 & 5 & 6 & 7 & 8 & 9 & 10 & 11 & 12 & 13 & 14 & 15 & 16 \\
\hline PG & 41.9 & 37.7 & 40.4 & 40.0 & 44.4 & 42.1 & 38.7 & 42.3 & 44.5 & 39.5 & 40.6 & 34.5 & 25.0 & 35.8 & 36.1 & 37.1 \\
CAL & 8.03 & 7.80 & 7.30 & 7.85 & 8.53 & 8.34 & 7.87 & 8.02 & 8.5 & 8.07 & 7.82 & 7.33 & 6.23 & 7.48 & 7.66 & 7.51 \\
CAPHY & 0.45 & 0.42 & 0.45 & 0.42 & 0.46 & 0.43 & 0.41 & 0.45 & 0.46 & 0.40 & 0.41 & 0.35 & 0.29 & 0.36 & 0.40 & 0.37 \\
CAPGO & 0.43 & 0.36 & 0.27 & 0.42 & 0.46 & 0.37 & 0.46 & 0.46 & 0.40 & 0.43 & 0.36 & 0.30 & 0.34 & 0.35 & 0.38 & 0.36 \\
TCUI & 102.2 & 92.8 & 95.6 & 92.5 & 81.1 & 87.1 & 92.1 & 95.5 & 92.1 & 79.2 & 75.5 & 73 & 72.6 & 75.8 & 84.7 & 90.6 \\
CI & 0.16 & 0.45 & 0.24 & 0.34 & 058 & 0.64 & 0.42 & 0.56 & 0.71 & 0.48 & 0.30 & 0.20 & 02 & 0.34 & 0.16 & 0.28 \\
Pr & 19.67 & 18.50 & 19.85 & 20.83 & 18.94 & 20.40 & 19.14 & 20.76 & 18.62 & 20.88 & 19.6 & 20.35 & 21.25 & 21.16 & 19.75 & 21.59 \\
\hline
\end{tabular}

Note. PG: weight of 100 seed; CAL: caliber of seed; CAPHY: capacity of hydratation; CAPGO: swelling capacity; TCUI: time of cooking; CI: index of color; Pr: rate of proteins.

The physical characreristics of seeds (Table 2) show variations and each cultivar or line excelled over other cultivars in one or other aspect. Line 13 has the best rate of proteins but the smallest caliber of seed and weight of 100 grains. The line 5 has the biggest caliber (8.53) and weight of 100 grains (44.4) but a small rate of proteins (18.94). The line 13 has a short time of cooking $(73 \mathrm{~min})$ and line 5 has longer time (81.1). These results showed availability of seeds with favourable characteristics useful for different utilization. In particular, the cultivars with small seeds that are not preferred by consumers seem to be interesting for processing in nutritional foods, flours and dietetics.

\subsection{Genetic Analysis}

\subsubsection{Heritability}

Table 3. Heritability of physicochemical and nutritional characters

\begin{tabular}{lllllllllll}
\hline Characters & PG & CAL & CAPHY & CAPGO & TCUI & HUM & CEND & DENS & CI & Pr \\
\hline Heritability & 0.774 & 0.767 & 0.704 & 0.140 & 0.420 & 0.083 & 0.067 & 0.015 & 0.419 & 0.181 \\
Standard-deviation & 0.085 & 0.087 & 0.1 & 0.164 & 0.159 & 0.159 & 0.157 & 0.151 & 0.159 & 0.16 \\
\hline
\end{tabular}

Note. PG: weight of 100 seeds; CAL: caliber; CAPHY: capacity of hydration; CAPGO: capacity of inflation; TCUI: time of cooking; HUM: humidity; CEND: ashes; DENS: density; CI: index of color; Pr: rate of proteins.

Two major types of heritability emerge from the Table 3 ; high value is registered for the weight of 100 grains $(\mathrm{H}$ $=0.77)$, the caliber of seeds $(H=0.76)$, the index color $(H=0.49)$, the time of cooking $(H=0.42)$ and the hydration capacity $(\mathrm{H}=0.70)$ whereas the rate of proteins $(\mathrm{H}=0.181)$ and ashes $(\mathrm{H}=0.067)$ have low heritability (because they are depending of environment and cultivation practices). So physicochemical characters are highly heritable and chemical characters are greatly influenced by environment (the minerals are provided to the plant by the soil and proteins are resulting from the chickpea symbiosis association with Rhizobium living in the soil).

Chickpeas are lower in protein than most other food legumes but have a higher digestibility; which tends to place them a par with other widely used pulses.

The correlation between the rate of proteins and the qualitative characters is very important to evaluate for the improvement of nutritional value in chickpea. 
Therefore this study deals with the correlations since few studies on the genetics of these characters have been accomplished; in fact most of the studies have focused on the correlations with yield especially.

The results and the correlation coefficients we obtained are in the following Tables 3, 4 and 5.

\subsubsection{Correlations}

Table 4. Correlations between nutritional and physicochemical characters

\begin{tabular}{lllllllll}
\hline & & Line & Pr & CAPHY & CI & CAL & CEND & DENS \\
\hline Line & Pearson Correlation & 1 & $.368^{*}$ & .105 & $.424^{* *}$ & $.327^{*}$ & .136 & .247 \\
& Sig. & & .010 & .476 & .003 & .023 & .357 & .090 \\
Pr & Pearson Correlation & $.368^{*}$ & 1 & .058 & .276 & -.139 & .168 & .016 \\
& Sig. & .010 & & .697 & .058 & .346 & .254 & .915 \\
CAPHY & Pearson Correlation & .105 & .058 & 1 & -.234 & .181 & .031 & .196 \\
& Sig. & .476 & .697 & & .109 & .218 & .832 & .182 \\
CI & Pearson Correlation & $.424^{* *}$ & .276 & -.234 & 1 & $-.334^{*}$ & .246 & -.014 \\
& Sig. & .003 & .058 & .109 & & .020 & .091 & .923 \\
CAL & Pearson Correlation & $.327^{*}$ & -.139 & .181 & $-.334^{*}$ & 1 & -.168 & .134 \\
& Sig. & .023 & .346 & .218 & .020 & & .255 & .365 \\
CEND & Pearson Correlation & .136 & .168 & .031 & .246 & -.168 & 1 & -.189 \\
& Sig. & .357 & .254 & .832 & .091 & .255 & & .197 \\
& Pearson Correlation & .247 & .016 & .196 & -.014 & .134 & -.189 & 1
\end{tabular}

Note. Rate of proteins (Pr), Hydration capacity (CAPHY), Index of color (CI), Caliber (CAL), Ashes (CEND), Density (DENS).

*: Correlation is significant at the 0.05 level (2-tailed); **: Correlation is significant at the 0.01 level (2-tailed).

The proteins, the index of color and the caliber are significantly correlated to line, so high humidity is not favorable to proteins; the efficiency of proteins Rhizobium synthesis is limited in conditions of more humidity. Among the environmental conditions, factors like rainfall, waterlogging and extremely high or low temperatures have a serious deleterious influence on the normal activity of the chickpea Rhizobium (Kantar et al., 2006).

The caliber of seeds is also affected conversely by more humidity because the vegetative growth is more important and delay the reproductive stage; so the duration of the size development of grains is shorter than in normal conditions and that is leading to smaller size of grains. The index of color is also decreasing in high humidity condition (more humidity is affecting the rate of synthesized pigments).

The index of color is highly heritable and significantly and conversely correlated with the caliber of seeds and then its improvement is possible with the aid of the index of color.

The capacity of hydration, density and the ashes are weakly correlated with the proteins, the caliber and the index of color. We can note that physical characters are independent of chemicals traits.

Nevertheless the ashes and color are mainly correlated (the coefficient of correlation is 0.246 in Table 3) so minerals are contributing to the color. Roots utilize specific and/or selective transport proteins to obtain all the minerals (usually as ions) that are essential for plant growth and development (i.e. $\mathrm{Ca}, \mathrm{Mg}, \mathrm{K}, \mathrm{P}, \mathrm{S}, \mathrm{Cl}, \mathrm{B}, \mathrm{Fe}, \mathrm{Mn}$, $\mathrm{Zn}, \mathrm{Cu}, \mathrm{Ni}$ and Mo) (Grusak \& DellaPenna, 1999).

It emerges also from the table above that the rate of proteins the caliber of seeds are conversely correlated $(-0,139$ in Table 3). This result is in accordance with the works of (Krishna Murti, 1975) who find that the protein concentration of chickpea seed ranges from $16.7 \%$ to $30.6 \%$ and $12.6 \%$ to $29.0 \%$ for desi and kabuli types respectively.

This property can be even exploited in the choice of varieties at the origin of flours being of use to the supply for children within the framework of the improvement of meal's nutritional value.

Besides the rate of proteins is significantly correlated with the index of color and weakly correlated with ashes. 
The ashes and density are conversely correlated; when minerals increase density decreases; the mass of minerals contained in seeds is lower with regard to the major other constituents of the seed such us starch, fatty acids or proteins.

It emerges from this results that the physical characters analyzed in Table 3 are not dependent and their simultaneous improvement with proteins is not easy directly.

In another hand the correlation between protein and line is significant $(0.368)$ and shows that irrigation in excess for chickpea is a factor's limiting synthesis (by means of chickpea Rhizobia); the blocks two and one have been irrigated respectively three and two times, and besides we have noted natural rain in first June after theses irrigations.

This result is in accordance with the studies of Kantar that concludes that among the environmental conditions, factors like rainfall, water logging and extremely high or low temperatures have a serious deleterious influence on the normal activity of the chickpea Rhizobium (Kantar et al., 2003).

The correlation between caliber and line shows that the caliber is bigger in the block 3 which doesn't received irrigation. This is confirming that vegetative development is much more important in conditions of irrigation than in rain fed conditions and theses practices are affecting reproductive stage which is delayed and grains are smaller.

The index of color and line are correlated positively so when humidity decreases the index of color increases (0.424). This is in accordance with the negative correlation of the index of color and humidity $(-0.19)$.

Table 5. Correlations between physicochemical and qualitative characters

\begin{tabular}{|c|c|c|c|c|c|c|c|c|c|c|}
\hline & & Line & $\operatorname{Pr}$ & HUM & $\mathrm{CI}$ & CAL & CEND & DENS & PG & TCUI \\
\hline \multirow[t]{2}{*}{ Line } & Pearson Correlation & 1 & $.368^{*}$ & .056 & $.424^{* *}$ & $.327^{*}$ & .136 & .247 & $.398^{* *}$ & .205 \\
\hline & Sig & & .010 & .706 & .003 & .023 & .357 & .090 & .005 & .162 \\
\hline \multirow[t]{2}{*}{$\operatorname{Pr}$} & Pearson Correlation & $.368^{*}$ & 1 & .000 & .276 & -.139 & .168 & .016 & -.166 & -.058 \\
\hline & Sig. & .010 & & .998 & .058 & .346 & .254 & .915 & .260 & .696 \\
\hline \multirow[t]{2}{*}{ HUM } & Pearson Correlation & .056 & .000 & 1 & -.219 & .158 & .008 & .200 & .029 & .259 \\
\hline & Sig. & .706 & .998 & & .135 & .284 & .956 & .172 & .843 & .075 \\
\hline \multirow[t]{2}{*}{ CI } & Pearson Correlation & $.424^{* *}$ & .276 & -.219 & 1 & $-.334^{*}$ & .246 & -.014 & -.228 & .032 \\
\hline & Sig. & .003 & .058 & .135 & & .020 & .091 & .923 & .119 & .828 \\
\hline \multirow[t]{2}{*}{ CAL } & Pearson Correlation & $.327^{*}$ & -.139 & .158 & $-.334^{*}$ & 1 & -.168 & .134 & $.905^{* *}$ & $.421^{* *}$ \\
\hline & Sig. & .023 & .346 & .284 & .020 & & .255 & .365 & .000 & .003 \\
\hline \multirow[t]{2}{*}{ CEND } & Pearson Correlation & .136 & .168 & .008 & .246 & -.168 & 1 & -.189 & -.106 & .044 \\
\hline & Sig. & .357 & .254 & .956 & .091 & .255 & & .197 & .473 & .769 \\
\hline \multirow[t]{2}{*}{ DENS } & Pearson Correlation & .247 & .016 & .200 & -.014 & .134 & -.189 & 1 & .155 & .283 \\
\hline & Sig. & .090 & .915 & .172 & .923 & .365 & .197 & & .292 & .051 \\
\hline \multirow[t]{2}{*}{ PG } & Pearson Correlation & $.398^{* *}$ & -.166 & .029 & -.228 & $.905^{* *}$ & -.106 & .155 & 1 & $.448^{* *}$ \\
\hline & Sig. & .005 & .260 & .843 & .119 & .000 & .473 & .292 & & .001 \\
\hline \multirow[t]{2}{*}{ TCUI } & Pearson Correlation & .205 & -.058 & .259 & .032 & $.421^{* *}$ & .044 & .283 & $.448^{* *}$ & 1 \\
\hline & Sig. & .162 & .696 & .075 & .828 & .003 & .769 & .051 & .001 & \\
\hline
\end{tabular}

Note. The rate of proteins (Pr), Humidity (HUM), Index of color (CI), Asches (CEND), Density (DENS), Caliber (CAL), Weight of 100 grains (PG), Time of cooking (TCUI).

*: Correlation is significant at the 0.05 level (2-tailed); **: Correlation is significant at the 0.01 level (2-tailed).

The weight of 100 seeds (PG) is significantly correlated with line; the weight of seeds substantially increases when one irrigation (the test is performed in the Mediterranean region where early spring doesn't receive rain sufficiently).

The time of cooking is significantly correlated with line so less humidity tends to the cooking time.

The correlation between the line and proteins is also significant this is showing that proteins are more abundant in natural conditions (block three) than in high humidity (block one and two). 
The correlation between the weight of 100 seeds and the caliber is very significant (0.902); seeds with big sizes are also of big weight. And then simultaneous improvement of weight and caliber is easily obtained.

The correlation of the time of cooking and the caliber is significant (0.421) and shows that seeds with big caliber have a longer time of cooking. Nevertheless this correlation can be broken by soaking the seed overnight before cooking. The correlation between the time of cooking and the rate of proteins is not significant (-0.058); so the selection for consumption of varieties with high rate of proteins and short cooking time is possibleSuch property gives to chickpea an increasing in the nutritional value (indeed the extension of heating duration in cooking is a factor of proteins denaturing).

The index of color and caliber have negative correlation (-0.334), so big sizes have less value of the index color and this is in agreement with the fact that the grains of desi type and of smaller size are dark colored.

The caliber of seeds in block three were the biggest (the blocks one and two have gave grains of smaller sizes), and then much irrigation in chickpea is not favorable to obtain big caliber.

Table 6. The correlations between qualitative characters

\begin{tabular}{|c|c|c|c|c|c|c|c|c|c|}
\hline & & PG & CAL & CAPHY & CAPGO & TCUI & HUM & CEND & DENS \\
\hline \multirow[t]{2}{*}{ PG } & Pearson Correlation & 1 & $.902^{* *}$ & $.580^{* *}$ & .112 & $.461^{* *}$ & -.108 & -.077 & .113 \\
\hline & Sig. & & .000 & .000 & .450 & .001 & .464 & .601 & .446 \\
\hline \multirow[t]{2}{*}{ CAL } & Pearson Correlation & $.902^{* *}$ & 1 & $.468^{* *}$ & $.298^{*}$ & $.421^{* *}$ & -.045 & -.149 & .106 \\
\hline & Sig. & .000 & & .001 & .040 & .003 & .762 & .312 & .472 \\
\hline \multirow[t]{2}{*}{ CAPHY } & Pearson Correlation & $.580^{* *}$ & $.468^{* *}$ & 1 & -.021 & .267 & -.047 & -.034 & .029 \\
\hline & Sig. & .000 & .001 & & .889 & .066 & .752 & .820 & .847 \\
\hline \multirow[t]{2}{*}{ CAPGO } & Pearson Correlation & .112 & $.298^{*}$ & -.021 & 1 & .250 & .020 & -.022 & -.165 \\
\hline & Sig. & .450 & .040 & .889 & & .086 & .891 & .883 & .263 \\
\hline \multirow[t]{2}{*}{ TCUI } & Pearson Correlation & $.461^{* *}$ & $.421^{* *}$ & .267 & .250 & 1 & -.272 & .169 & .257 \\
\hline & Sig. & .001 & .003 & .066 & .086 & & .061 & .252 & .078 \\
\hline \multirow[t]{2}{*}{ HUM } & Pearson Correlation & -.108 & -.045 & -.047 & .020 & -.272 & 1 & -.140 & -.084 \\
\hline & Sig. & .464 & .762 & .752 & .891 & .061 & & .342 & .568 \\
\hline \multirow[t]{2}{*}{ CEND } & Pearson Correlation & -.077 & -.149 & -.034 & -.022 & .169 & -.140 & 1 & -.121 \\
\hline & Sig. & .601 & .312 & .820 & .883 & .252 & .342 & & .411 \\
\hline \multirow[t]{2}{*}{ DENS } & Pearson Correlation & .113 & .106 & .029 & -.165 & .257 & -.084 & -.121 & 1 \\
\hline & Sig. & .446 & .472 & .847 & .263 & .078 & .568 & .411 & \\
\hline
\end{tabular}

Note. Hydration capacity (CAPHY), Soaking capacity (CAPGO), Caliber (CAL), Ashes (CEND), Density (DENS), Humidity (HUM), Weight of 100 grains (PG), Time of cooking (TCUI).

**: Correlation is significant at the 0.01 level (2-tailed); *: Correlation is significant at the 0.05 level (2-tailed).

We note strong correlations between PG/CAL (0.902); PG/CAPHY (0.580) and CAPHY/TCUI (0.461) whish show that the characters the weight of 100 seeds (PG), the caliber (CAL), the capacity of hydration (CAPHY) and the time of cooking (TCUI) are dependant genetically so we can exploit this result in breeding programs for the improvement of chickpea quality.

We note that the weight of 100 seed is weakly correlated to the capacity of soaking $(0.112)$ because the latter depends on the structure and thickness of seed coat and is independent of seed mass. The time of cooking and humidity are conversely correlated; the dryer the seed is the longer the cooking time.

Besisdes, several authors studied the effect of cooking (extrusion, roasting) on the textural, functional and nutritional properties of chickpea. (Kaur et al., 2010) showed a negative correlation between the properties of inflation during the roasting and the weight, the volume and the capacity of hydration of the seeds. On the other hand, the extrusion improves the digestion of the flour of chickpea because temperature pulls the desactivation and the denaturation of proteins making them more accessible to the action of enzymes (Millan-Carillo, 2009).

Among the cool season legumes, chickpea is the most tolerant crop but, the crop does respond positively to irrigation. Commonly the crop is growing on conserved moisture at the end of rainy season so supplemental irrigation to relieve moisture shortage at critical stages is a practice of culture in chickpea producing regions. 
Under Tunisian conditions chickpea crop growing at early winter, the seed quality increases for one, two irrigations and it started declining with three irrigations.

The proteins are the most important nutritional character from the viewpoint of nutritionists, nevertheless the weight of 100 seeds, the caliber, the hydration capacity and the time of cooking receive also a great interest by breeders because they represent the seed quality looked for by the consumer.

Strong correlations are noted between the weight of 100 seeds and the caliber $(0,902)$ and high correlations are registered between the weight of 100 seeds and the hydration capacity $(0,580)$ and also between the hydration capacity and the time of cooking $(0,461)$. These results are useful in breeding programs and show that a simultaneous improvement is possible of these characters in early generations. For the proteins the improvement seems to be more slowly (the correlations are weak with the studied characters), but culture practices may give substantially enhancements; the data show that supplemental irrigation is advantageous to protein's rate when the number doesn't exceed two irrigations. We also note that positive result is registered for the weight of 100 seeds and the caliber.

The coefficients of correlations are significant between the time of cooking and the caliber $(0,421)$ and between the time of cooking and the weight of 100 seeds $(0,448)$ (Table 4). Besides the weight of 100 seeds and the caliber have high heritability respectively $(\mathrm{H}=0,774$ and 0,767$)$ (Table 2). Therefore Cooking time is a potentially improvable character whose including in breeding programs is beneficial. Both agronomic and genetic approaches are complementary and are leading to improve seed quality (i.e. weight, caliber, hydration capacity and cooking time). Supplemental irrigation and specific cultural practices are much more effective than breeding to improve the rate of proteins in Chickpea.

\section{References}

Duhan, A., Khetarpaul, N., \& Bishnoi, S. (1999). In starch digestibility (in vitro) of various pigeonpea cultivars through processing cooking. Ecology of food and Nutrtion, 37, 557-568. https://doi.org/10.1080/03670244. 1998.9991565

Gervani, P. (1991). Utilization of chickpea in India and scope for novel and alternative uses. Uses of Tropical Grain Legumes, Proceedings of Consultants Meeting (pp. 47-54). ICRISAT Center Patancheru, Andhra, Pradesh, India.

Grusak, M. A., \& DellaPenna, D. (1999). Improving the nutrient composition of plants to enhance human nutrition and health. Annual Review of Plant Physiology and Plant Molecular Biology, 50, 133-161. https://doi.org/10.1146/annurev.arplant.50.1.133

Jimenez-Cuesta, M., Cuquerella, J., \& Martinez-Javega, J. M. (1981). Determination of color index for citrus degreening. Proceedings of the International Society of Citriculture, 2, 750-753.

Kantar, F., Elkoca, E., Ogutcu, H., \& Algur, O. F. (2003). Chickpea yields in relation to Rhizobium inoculation from wild chickpea at high altitudes. Journal of Agronomy and Crop Science, 189, 1-7. https://doi.org/10.1046/j.1439-037x.2003.00046.x

Kantar, F., Hafeez, F. Y., Shivakumar, B. G., Sandaram, S. P., Tejera, N. A., Aslam, A., ... Raja, P. (2006). Chickpea: Rhizobium management and Nitrogen Fixation. Chickpea Management and Breeding (p. 169).

Kaur, M., \& Singh, N. (2005). Studies on functional, thermal and pasting properties of flours from different chickpea (Cicer arietinum L.) cultivars. Food Chem., 91(3), 403-411. https://doi.org/10.1016/ j.foodchem.2004.06.015

Kaur, M., Singh, N., \& Sodhi, N. (2005). Physicochemical, cooking, textural and roasting characteristics of chickpea (Cicer arietinum L.) cultivars. Journal of Food Engineering, 69, 511-517. https://doi.org/10.1016/ j.jfoodeng.2004.09.002

Krishna Murti, C. R. (1975). Biochemical studies on bengal gram. Journal of Scientific and Industrial Research, $34,266-281$.

Leterme, P. (2002). Recommendations by health organizations for pulse consumption. British Journal of Nutrition, 88, 239-242. https://doi.org/10.1079/BJN2002712

Millan-Carillo, J. (2009). The optimum conditions for the production of extruded flour from hardened Chickpeas (Cicer arietinum L.) for bakery products. Journal of Food Process Engineering, 32(2), 294. 
Paolini, R., Colla, G., Saccardo, F., \& Campiglia, E. (2003). The influence of plant crop density on the efficacy of mechanical and reduced chemical weed in lentil (Lens culinaris Medik). Indian journal of Agronomy, 7, 85-94.

Rupperez, P. (1998). Oligosaccharides in raw and processed legumes, Food Research and Technology, 206, 130-133. https://doi.org/10.1007/s002170050228

WHO/FAO. (2003). Diet, nutrition and the prevention of chronic diseases: Report of a joint WHO/FAO expert consultation. WHO Technical Report Series 916 (p. 160). World Health Organization (WHO) and the Food and Agriculture Organization (FAO) of the United Nations, Geneva.

Williams, P. C., \& Singh, U. (1986). Nutritional Quality and the Evaluation of Quality in Breeding Programmes. In M. C. Saxena, \& K. B. Singh (Eds.), Chickpea (p. 351). CAB International Oxford, UK.

Williams, P. C., \& Singh, U. (1988). Quality screening and evaluation in pulse breeding. In R. J. Summerfield (Ed.), World crops, cool season food legume (pp. 445-457). Dordrecht, The Netherlands: Kulwer Academic Publishers. https://doi.org/10.1007/978-94-009-2764-3_38

Williams, P. C., Singh, K. B., \& Nakkoul, H. (1983). Relation of some physical aspects of Kabuli type chickpeas to cooking time. Journal of the science of Food and Agriculture, 34, 492-6. https://doi.org/10.1002/ jsfa. 2740340510

Williams, P., El-Haramein, F. J., Nakkoul, H., \& Rihawi, S. (1986). Crop Quality Evaluation Methods and Guideliness. Technical Manual 14 (Rev. 1). ICARDA.

Yadav, S. S., Redden, R. J., Chen, W., \& Sharma, B. (2006). Chickpea Management and Breeding (p. 102).

\section{Copyrights}

Copyright for this article is retained by the author(s), with first publication rights granted to the journal.

This is an open-access article distributed under the terms and conditions of the Creative Commons Attribution license (http://creativecommons.org/licenses/by/4.0/). 